Brief communication

\title{
Second-line chemotherapy with long-term low-dose oral etoposide in patients with advanced breast cancer
}

\author{
M. Bontenbal, A.S.Th. Planting, J. Verweij, R. de Wit, W.H.J. Kruit, G. Stoter and J.G.M. Klijn \\ Department of Medical Oncology, Rotterdam Cancer Institute (Dr. Daniel den Hoed Kliniek), Groene Hill- \\ edijk 301, 3075 EA Rotterdam, The Netherlands
}

Key words: breast cancer, oral etoposide, phase II

\section{Summary}

In a phase II study, 27 patients with metastatic breast cancer were treated with oral etoposide as second-line chemotherapy at a dose of $50 \mathrm{mg} / \mathrm{m}^{2} /$ day for 21 days, which courses were repeated every 4 weeks. Twenty-one patients were evaluable for response, and twenty-five for toxicity. In two (10\%) patients a partial response was observed with a duration of 60 and 122 weeks respectively, and seven patients (33\%) showed stable disease. Gastrointestinal toxicity was usually mild, though relatively frequent. Anemia grade II and III was observed in $20 \%$ of all courses ( $<10 \%$ of all measurements), and leukopenia grade III and IV was observed in $22 \%$ of all courses $(<10 \%$ of all measurements). There was one toxic death.

Reviewing the literature we calculated a response rate of intravenous etoposide treatment of $8 \%$ in 276 patients with metastatic breast cancer from 7 studies (response rates ranging between $0-14 \%$ ), while (chronic) oral treatment caused a response rate of $19 \%$ in 145 patients from 8 different studies (response rates ranging between $0-35 \%$ ).

\section{Introduction}

The prognosis of patients with disseminated breast cancer refractory to or relapsing from first-line chemotherapy is poor. All currently applied cytotoxic drugs yield low response rates $(10-30 \%)$ with a median duration of response of about 6 months or less and frequently considerable toxicity [1]. Therefore, new approaches are warranted. Because breast cancers contain usually a relatively low percentage of proliferating cells within the cell cycle, prolonged exposure to a cytotoxic drug is theoretically attractive.

Etoposide (VP16-213), a semisynthetic podophyllotoxin derivative with a wide antitumor activ- ity, is a cell cycle phase-specific drug acting in the late $S$ - and early $G_{2}$-phase of the cell cycle with schedule dependency [2]. Activity of the drug is probably more related to duration of exposure to tumor cells rather than to the area under the curve (AUC) [3-5]. Etoposide has been used in clinical trials for approximately 20 years without clear efficacy in breast cancer, but recently there is renewed interest in this drug because of the application of new treatment schedules $[6,7]$. There is clinical evidence that chronic daily administration of oral etoposide can induce responses in patients with different chemotherapy refractory solid tumors $[8,9]$.

Out of the four breast cancer patients in a phase I trial using prolonged low-dose oral etoposide [8], 
one had an objective response and one patient with non-measurable disease had a subjective response. Based on these data we initiated a phase II study with daily oral administration of etoposide as second-line chemotherapy in patients with metastatic breast cancer.

\section{Patients and methods}

Eligibility criteria of this study included patients with measurable or evaluable lesions, age less than 80 years, World Health Organization (WHO) performance score (PS) 2 or less, life expectancy of more than 2 months, serum bilirubin less than $20 \mu \mathrm{mol} / \mathrm{l}$, WBC above $3.0 \times 10^{9} / \mathrm{l}$, platelets above $100 \times 10^{9} / 1$, no prior therapy with etoposide. Patients with a history of recent cardiac disease, or patients with metastases in the central nervous system, were excluded. Metastatic disease of all patients was considered resistant to previous endocrine therapy and to first-line chemotherapy. All patients gave oral informed consent before entering the study.

On-study evaluation consisted of medical history, physical examination, tumor measurements, complete blood count ( $\mathrm{Hb}, \mathrm{WBC}$, platelets), automated blood chemistry, bonescan, bone and chest X-rays, and CT-scan or ultrasound of the liver in case of liver metastases. On follow-up complete blood count was performed weekly and response evaluation was performed after every second course.

Treatment consisted of etoposide $50 \mathrm{mg} / \mathrm{m}^{2} /$ day, orally for three consecutive weeks, in a twentyeight day cycle. Responses and toxicity were defined according to WHO criteria. Duration of complete and partial response was measured from initiation of therapy till time of tumor progression.

\section{Results}

Twenty-seven patients entered the study. Patient characteristics are indicated in Table 1. Two of the 27 patients were ineligible (PS: 3 and bilirubin $43 \mu \mathrm{mol} / \mathrm{l})$. All 25 eligible patients were evaluable for toxicity. The total number of courses of etoposide administered was 90 (mean: 3.6; median 2, range 1-25). Gastrointestinal toxicity was usually mild. Twenty-two patients had no or only mild complaints of nausea (WHO grade 0-1), while four patients $(16 \%)$ experienced nausea and vomiting grade II-III, for which reason one of them was hospitalized. Alopecia was often related to previous chemotherapy, while in three patients the first hair loss (grade II-III) was undoubtedly etoposide-induced. Leukopenia grade III and IV occurred in 15 patients $(60 \%)$, in $22 \%$ of all courses, and in $<10 \%$ of all measurements; anemia grade II and III was observed in 9 patients (36\%), in $20 \%$ of all courses, and in $<10 \%$ of all measurements. Mild to moderate thrombocytopenia was infrequent (grade I-II: in $3 \%$ of all measurements). One patient died during the leukopenic period.

Four of the 25 eligible patients were not evaluable for response because of early withdrawal (within the first 3 weeks). Reasons to stop the treatment

Table 1. Patient characteristics

\begin{tabular}{|c|c|}
\hline Number of patients entered & 27 \\
\hline Number of eligible patients & 25 \\
\hline \multicolumn{2}{|l|}{ Number of patients evaluable } \\
\hline for response & 21 \\
\hline for toxicity & 25 \\
\hline \multicolumn{2}{|l|}{ Age } \\
\hline median (range) & $54(37-76)$ \\
\hline \multicolumn{2}{|l|}{ WHO performance status } \\
\hline $\begin{array}{l}\text { No of organ systems involved } \\
\text { median (range) }\end{array}$ & $3(1-5)$ \\
\hline \multicolumn{2}{|c|}{$\begin{array}{l}\text { Time from first sign of metastatic disease to start of } \\
\text { etoposide (months) }\end{array}$} \\
\hline median (range) & $19(4-81)$ \\
\hline \multicolumn{2}{|l|}{ No of prior hormonal therapies } \\
\hline median (range) & $1(0-4)$ \\
\hline \multicolumn{2}{|l|}{ Prior chemotherapy } \\
\hline Adjuvant & 7 \\
\hline Chemotherapy for metastatic disease & 27 \\
\hline Cyclophosphamide/Methotrexate/Flurouraci & 118 \\
\hline Cyclophosphamide/Doxorubicin/Fluorouraci & il 8 \\
\hline Cyclophosphamide/Epirubicin/Fluorouracil & 1 \\
\hline \multicolumn{2}{|l|}{ Site of metastatic lesion } \\
\hline liver & 10 \\
\hline lung & 7 \\
\hline pleura & 6 \\
\hline bone & 17 \\
\hline lymph node & 5 \\
\hline skin & 11 \\
\hline breast & 6 \\
\hline
\end{tabular}




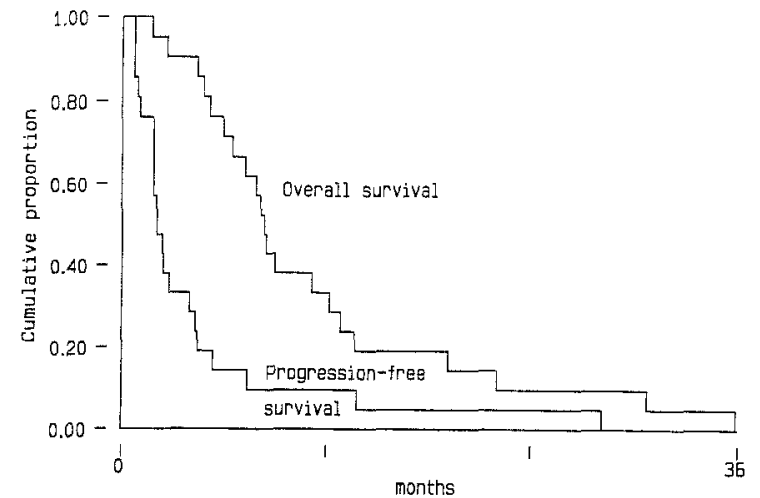

Fig. 1. Median survival time.

in these 4 patients were: severe nausea and vomiting (1), analysis of polyuria (1), anemia (1), and sudden death in a patient with an axillary thrombosis two weeks after start of therapy. No complete responses were observed in 21 patients evaluable for response. Two patients $(10 \%)$ (95\% confidence interval $1-30 \%$ ) achieved a partial response with a duration of 60 and 122 weeks, respectively. The first responding patient was treated before with hormonal therapy for 3 months without success, followed by 12 courses of FEC chemotherapy with stabilisation of the disease. During etoposide treatment the lytic bone metastases showed fair sclerosis. The second patient had been treated for three years with two lines of endocrine therapy, followed by 23 courses of CMF chemotherapy with a partial response. During etoposide therapy the pulmonary lesions showed a partial response and the bone lesions remained stable.

Seven patients $(33 \%)$ had stable disease with a median duration of 19 weeks (range $9^{+}-32$ weeks). Progressive disease from the start of treatment was observed in twelve patients. For the 21 evaluable patients the median time to progression was 2 months (mean: 4.3 months) and the median survival time was 8.3 months (mean: 11.3 months) (Fig. 1).

\section{Discussion}

Treatment results of second-line chemotherapy in metastatic breast cancer are disappointing and remissions are usually of short duration [1]. There- fore, testing of new treatment modalities remains of utmost importance.

In the past twenty years etoposide has been extensively used in the treatment of patients with a variety of solid tumors. Most experience with etoposide in breast cancer is obtained with intravenous (i.v.) treatment schedules. Table 2 summarizes the treatment results with etoposide in this disease. Seven studies (concerning 276 patients) applied i.v. etoposide as a single agent in previously treated patients. Response percentages varied from $0-14 \%$, with an overall response rate of only $8 \%$ [10-16].

Table 2. Etoposide as $\geq$ second-line single agent therapy in metastatic breast cancer

Treatment schedule No. of Response Ref. eval. pts $(\mathrm{CR}+\mathrm{PR})$

$$
\text { n } \%
$$

\begin{tabular}{|c|c|c|c|c|}
\hline \multicolumn{5}{|l|}{ Intravenous administration } \\
\hline $100-250 \mathrm{mg} / \mathrm{m}^{2}$ q every week & 14 & 0 & 0 & 10 \\
\hline $45 \mathrm{mg} / \mathrm{m}^{2}$ days $1-5 \mathrm{q} 3 \mathrm{wk}$ & 60 & 3 & 5 & 11 \\
\hline $75 \mathrm{mg} / \mathrm{m}^{2}$ days $1-5 \mathrm{q} 3 \mathrm{wk}$ & 59 & 5 & 8 & \\
\hline $50-70 \mathrm{mg} / \mathrm{m}^{2}$ days $1-5 \mathrm{q} 3 \mathrm{wk}$ & 35 & 5 & 14 & 12 \\
\hline $50-70 \mathrm{mg} / \mathrm{m}^{2} \mathrm{CI}$ days $1-5 \mathrm{q} 3 \mathrm{wk}$ & 31 & 4 & 13 & \\
\hline $60-135 \mathrm{mg} / \mathrm{m}^{2}$ twice weekly & 24 & 1 & 4 & 13 \\
\hline $125 \mathrm{mg} / \mathrm{m}^{2}$ days $1,3,5 \mathrm{q} 3-4 \mathrm{wk}$ & 19 & 0 & 0 & 14 \\
\hline $100-125 \mathrm{mg} / \mathrm{m}^{2}$ days $1,3,5 \mathrm{q} 4-5 \mathrm{wk}$ & 19 & 2 & 11 & 15 \\
\hline $300-450 \mathrm{mg} / \mathrm{m}^{2}$ days $1-3 \mathrm{q} 4 \mathrm{wk}$ & 15 & 1 & 7 & 16 \\
\hline Total & 276 & 21 & 8 & \\
\hline \multirow[t]{2}{*}{ Treatment schedule } & $\begin{array}{l}\text { No. of } \\
\text { eval. pts }\end{array}$ & \multicolumn{2}{|c|}{$\begin{array}{l}\text { Response } \\
(\mathrm{CR}+\mathrm{PR})\end{array}$} & Ref. \\
\hline & & $\mathrm{n}$ & $\%$ & \\
\hline \multicolumn{5}{|l|}{ Oral administration } \\
\hline $75-125 \mathrm{mg} / \mathrm{m}^{2}$ days $1-5 \mathrm{q} 3 \mathrm{wk}$ & 14 & 0 & 0 & 10 \\
\hline $\begin{array}{l}200 \mathrm{mg} / \text { day days } 1-5 \text { q } 2-3 \mathrm{wk} \text { or } \\
300-400 \mathrm{mg} / \text { day days } 1-5 \mathrm{q} 2 \mathrm{wk}\end{array}$ & 20 & 0 & 0 & 17 \\
\hline $50 \mathrm{mg} / \mathrm{m}^{2} /$ day; days $1-21 \mathrm{q} 4 \mathrm{wk}$ & 4 & 1 & 25 & 8 \\
\hline $50 \mathrm{mg} / \mathrm{m}^{2} /$ day; days $1-21 \mathrm{q} 4$ wk & 18 & 4 & 22 & 18 \\
\hline $50 \mathrm{mg} / \mathrm{m}^{2} /$ day; days $1-21 \mathrm{q} 4 \mathrm{wk}$ & 43 & 15 & 35 & 19 \\
\hline $50 \mathrm{mg} /$ day; days $1-14 \mathrm{q} 4 \mathrm{wk}$ & 10 & 1 & 10 & 20 \\
\hline $50 \mathrm{mg} / \mathrm{m}^{2} /$ day; days $1-21 \mathrm{q} 4 \mathrm{wk}$ & 25 & 5 & 25 & 21 \\
\hline $50 \mathrm{mg} / \mathrm{m}^{2} /$ day; days $1-21 \mathrm{q} 4 \mathrm{wk}$ & 21 & 2 & 10 & $\begin{array}{l}\text { This } \\
\text { study }\end{array}$ \\
\hline Total & 145 & 28 & 19 & \\
\hline
\end{tabular}

$\mathrm{CI}=$ continuous infusion. 
Thus these short-term intravenous schemes of second-line chemotherapy with etoposide have shown only moderate activity in breast cancer, while toxicity was generally considered acceptable with myelosuppression emerging as the most frequent side effect.

Treatment results of eight studies (including our study) using oral etoposide as second-line chemotherapy in metastatic breast cancer are also shown in Table $2[8,10,17-21]$. In the studies of Cavalli et al. [10] and Falkson et al. [17] using a high dose oral regimen for five days no responses were observed. However, because the cytotoxic effect of etoposide is more related to the duration of tumor cell exposure to the drug rather than to the AUC, prolonged exposure might theoretically result in an augmented anti-tumor effect [3-5]. In a phase I trial [8] one out of 4 patients with breast cancer responded to a long-term low-dose etoposide regimen. The recommended dose for following phase II studies was therefore $50 \mathrm{mg} / \mathrm{m}^{2} /$ day for 21 days in a 28 day cycle. We performed a phase II study using this regimen but achieved only $10 \%$ remissions. Palombo et al. [18], Martin et al. [19], and Atienza et al. [21] performed similar studies in breast cancer patients pretreated with chemotherapy. They reported higher response rates, i.e. $22 \%, 35 \%$ and $25 \%$, respectively (Table 2). On the other hand Calvert et al. [20] reported the same response rate of $10 \%$ in a subgroup of 10 patients treated with $50 \mathrm{mg}$ etoposide per day after previous chemotherapy. In this heterogeneous study higher response rates were observed in a subgroup of chemotherapy naive patients ( $45 \%$ response) and at a higher dose (100 $\mathrm{mg} /$ day) regimen (35\% response, regarding mainly patients not treated with chemotherapy before). When taking together all literature data, (chronic) oral etoposide treatment caused an objective response in $19 \%$ of 145 patients (Table 2) [8,10,17-21], mostly of short duration. Responses can occur in all types of metastatic sites. The toxicity observed in our study is comparable with those of other studies with leucopenia as the most serious side effect. Also Calvert et al. [20] and Atienza et al. [21] reported the occurrence of toxic deaths, although this outpatient regimen appeared to be quite manageable.

In conclusion, second-line chemotherapy with etoposide has only moderate activity in patients with metastatic disease in the presence of significant but manageable toxicity. Newer agents such as taxol and taxotere might therefore be of greater interest $[22,23]$, but maybe etoposide can be of greater value in combination with these or other active agents.

\section{References}

1. Henderson IC, Allegra JC, Woodcock Th et al: Randomized clinical trial comparing mitoxantrone with doxorubicin in previously treated patients with metastatic breast cancer. J Clin Oncol 7: 560-571, 1989

2. Clark PI, Slevin ML: The clinical pharmacology of etoposide and teniposide. Clin Pharmacokin 12: 223-252, 1987

3. Slevin ML, Clark PI, Joel SP et al: A randomized trial to evaluate the effect of schedule on the activity of etoposide in small cell lung cancer. J Clin Oncol 9: 1333-1340, 1989

4. D'Incalci M, Erba $\mathrm{E}$, Vaghi $\mathrm{M}$ et al.: In vitro cytotoxicity of VP16 on primary tumour and metastasis of Lewis lung carcinoma. Eur J Cancer Clin Oncol 18: 377-380, 1982

5. Hill BT, Whetan RDH, Rupniak HT et al: : A comparative assessment of the in vitro effects of drugs on cells by means of colony assays on flow microfluorimetry. Cancer Chemother Pharmacol 7: 21-26, 1982

6. Comis RL: Oral etoposide in oncology: an evolving role. Ann Oncol 3: 63-67, 1992

7. Sledge GW: Etoposide in the management of metastatic breast cancer. Cancer 67: 266-270, 1991

8. Hainsworth JD, Johnson DH, Frazier SR, Greco FA: Chronic daily administration of oral etoposide. A phase I trial. J Clin Oncol 7: 396-401, 1989

9. Miller JC, Loehrer PJ, Williams SD, Einhorn LH: Phase II study of oral VP-16 in refractory germ cell tumors. Proc ASCO 8: 145,1989

10. Cavalli F, Jungi WF, Brunner KW: Randomisierte Phase II Studie mit VP-16-213 (Etoposide) in der Behandlung vom fortgeschrittenen Mammakarzinom. Onkologie 4: 80-83, 1981

11. Vaughn CB, Panettiere F, Thigpen T, Bottomley R, Hoogstraten B, Samal B: Phase II evaluation of VP-16-213 in patients with advanced breast cancer: A Southwest Oncology Group study. Cancer Treat Rep 65: 443-445, 1981

12. Schell FC, Yap HY, Hortobagyi GN, Esparza L: Phase II study of VP16-213 (Etoposide) in refractory metastatic breast carcinoma. Cancer Chemother Pharmacol 7: 223 225,1982

13. Nissen NI, Pajak TF, Leone LA, Bloomfield CD, Kennedy BJ, Ellison RR, Silver RT et al: Clinical trial of VP 16-213 (NSC 141540) i.v. twice weekly in advanced neoplastic disease. A study by the Cancer and Leukemia Group B. Cancer 45: 232-235, 1980 
14. Ahmann DL, Bisel HF, Eagan RT, Edmonson JH, Hahn RG, O'Connell MJ, Frytak S: Phase II evaluation of VP-16213 (NSC-141540) and Cytembena (NSC-104801) in patients with advanced breast cancer. Cancer Treat Rep 60: 633-635, 1976

15. Eagan RT, Ahmann DL, Bisel HF: Evaluation of VP-16 and the combination of Adriamycin and Vincristine in advanced breast cancer. Oncology 33: 146-148, 1976

16. Fraschini G, Esparza L, Holmes F, Tashima C, Theriault R, Hortobagyi G: High-dose Etoposide in metastatic breast cancer. (Abstr). Breast Cancer Res Treat 14: 142, 1989

17. Falkson G, van Deyk JJ, van Eden EB, van der Merwe AM, van den Bergh JA, Falkson HC: A clinical trial of the oral form of $4^{\prime}$-demethyl-epipodophyllotoxin- $\beta-\mathrm{D}$ ethylidene glucoside (NSC 141540), VP 16-213. Cancer 35: 1141-1144, 1975

18. Palombo H, Estapé J, Viñolas N, Grau JJ, Mañé JM, Daniels M, Mellado B: Chronic oral Etoposide in advanced breast cancer. Cancer Chemother Pharmacol 33: 527-529, 1994

19. Martin M, Lluch A, Casado A, Santabarbara P, Adrover E, Valverde J, Lopez-Martin J, Rodriguez-Lescure A, Azagra
P, Garcia-Conde J, Diaz-Rubio E: Clinical activity of chronic oral etoposide in previously treated metastatic breast cancer. J Clin Oncol 5: 986-991, 1994

20. Calvert AH, Lind MJ, Millward MM, Cantwell BMJ, Gumbrell L, Proctor M, Simmons D, Chapman F, Robinson A, Charlton C, Balmanno K, Newell D: Long-term oral etoposide in metastatic breast cancer: clinical and pharmacokinetic results. Cancer Treat Rev 19 suppl. C: 27-33, 1993

21. Atienza DM, VogeI CL, Trock B, Swain SM: Phase II study of oral VP-16-213 (etoposide) in patients with advanced breast cancer (Abstr). Breast Cancer Res Treat 27: 146, 1993

22. Nabholtz JM, Gelmon K, Bontenbal M, Spielmann M, Clavel M, Seeber S, Conte P, Namer M, Bonneterre J, Fumoleau P, Sulkes A, Sauter Ch, Roche H, Calvert H, Kaufmann J, Chazard M, Diergarten K, Gallant G, Thompson M, Winograd B, Onetto N: Randomized trial of two doses of taxol in metastatic breast cancer: an interim analysis. Proc ASCO12: 60,1993

23. Verweij J, Clavel M, Chevallier B: Paclitaxel (Taxol ${ }^{\mathrm{TM}}$ ) and Docetaxel (Taxotere ${ }^{\mathrm{TM}}$ ): not simply two of a kind. Ann Oncol 5: 495-505, 1994 